\title{
ОБ ОСНОВАНИЯХ ДЕЙСТВИТЕЛЬНОСТИ ПРАВА, СОВРЕМЕННОМ ПРАВОПОНИМАНИИ И НАУЧНОЙ РАЦИОНАЛЬНОСТИ ПРАВОВЕДЕНИЯ В ЦИФРОВУЮ ЭПОХУ'1
}

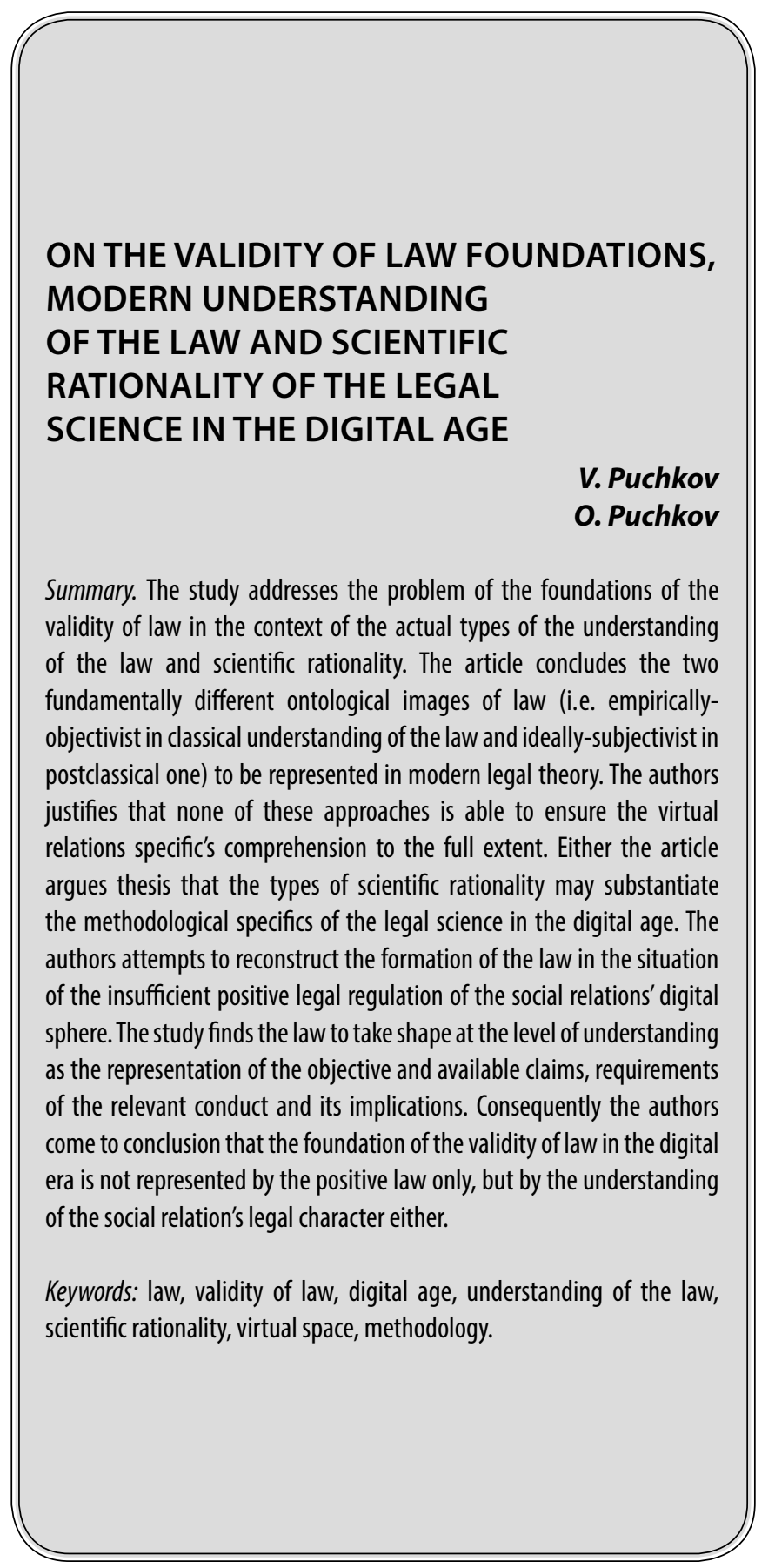

\author{
Пучков Владислав Олегович \\ Соискатель, Уральский государственный \\ юридический университет \\ Пучков Олег Александрович \\ Д.ю.н., профессор, Уральский государственный \\ юридический университет \\ puchkovandpartners@gmail.com
}

Аннотация. В статье рассматривается проблема оснований действительности права в контексте актуальных типов правопонимания и научной рациональности. Делается вывод, что в современном правопонимании представлены две принципиально различные онтологические картины права (эмпирико-объективистская - в классическом правопонимании, идеально-субъективистская - в постклассическом правопонимании). Авторы обосновывают, что ни один из данных подходов не способен в полной мере обеспечить осмысление специфики социальных отношений в виртуальной сфере. Также в статье подвергается сомнению тезис о возможности обоснования методологической специфики правоведения цифровой эпохи в контексте типов научной рациональности. Авторы предпринимают попытку осуществить реконструкцию процесса правообразования в ситуации недостаточности позитивно-правового регулирования цифровой сферы общественных отношений. Формулируется вывод о том, что право первоначально формируется на уровне понимания как представленность в сознании объективно существующих притязаний, требований соответствующего поведения и последствий реализации данных явлений. Вследствие этого авторы приходят к выводу, что в цифровую эру основанием действительности права является не только наличие позитивного права, но и понимание правового характера того или иного общественного отношения.

Ключевые слова: право, действительность права, цифровая эпоха, правопонимание, научная рациональность, виртуальное пространство, методология.

Исследование выполнено при поддержке Российского фонда фундаментальных исследований в рамках научного проекта № 18-29-16148 «Трансформация права в условиях развития цифровых технологий». 
В основе науки о праве... лежит существенное недоразумение относительного того, в какой сфере можно найти и наблюдать правовые явления и как их следует изучать

\section{Л. И. Петражицкий [1, с. 34]}

$\longrightarrow$ точки зрения основного разделения всех наук на естественные и гуманитарные правоведение, без сомнения, является гуманитарной наукой. Основания такого подхода в принципе понятны: правовая действительность носит производный характер от реальности общественных отношений, и в этом смысле вне человека, вне сообщества людей права нет ${ }^{1}$. Отсюда следует, что само право как предмет научного осмысления не является природным (в смысле естествознания) явлением, а представляет собой по существу идеальный объект ${ }^{2}$, явление, не существующее за пределами реальности, конституируемой нашим сознанием ${ }^{3}$. В этом контексте оправданно считать, что право наряду, к примеру, с языком, культурой, искусством и т.п. относится к числу гуманитарных феноменов, и что, соответственно, методология научного познания права развивается в парадигме гуманитаристики

Такова общая науковедческая картина онтологии правовой науки. Prima facie подобная концепция является если не бесспорной, то во всяком случае не лишенной определенных философско-методологических оснований. В то же время не следует упускать из виду то обстоятельство, что право в такой логике является системным явлением, поскольку как предмет научного познания оно не существует изолированно как от гуманитарных, так и от естественных, природных феноменов $^{5}$. Системные свойства права опосредуются в этом смысле двумя аспектами, которые можно терминологически обозначить в качестве «внешнесистемного» и «внутрисистемного». Внешнесистемный аспект права обусловлен его институциональной природой, взаимосвязанностью и взаимообусловленностью права

\footnotetext{
1 «Ubi societas, ibi ius» («где общество, там и право» (лат.)) - утверждали римские юристы [2, с. 113].

2 «Идеальный объект в данном контексте,- пишет М.А.Розов, - это объект, свойства которого обусловлены не его материалом, не его физической природой, а некоторыми социальными программами» [3, с. 41]. См. также: [4, с. 190]

3 Рассматривая специфику гуманитарных наук, П.А. Сорокин писал, что «содержание, предмет изучения, внутренняя структура, методология обусловлены здесь типом доминантной культуры (курсив наш - В.П., О.П.)» [5, с. 467].

${ }^{4}$ Попытки представить право в качестве природного (в смысле естествознания) явления, предпринятые школой юснатуралистов, показали в этом смысле свою методологическую несостоятельность [6, с. 40].

5 О системном характере организации объектов научного познания см.: $[7$, c. $9-10 ; 8$, c. 96].
}

всем комплексом иных явлений как гуманитарного, так и естественного плана. Здесь в качестве примера можно обратиться к факторам религиозного порядка, обусловившим формирование религиозного правового семейства (систем мусульманского, индуистского, иудейского права), к факторам экономико-идеологического порядка, вследствие которых появилось социалистическое право, к факторам антропологического порядка, конституирующих традиционные правовые системы и т.п. Существенное влияние на право оказывают также факторы технического и технологического плана. Показательным примером являются в заданном контексте дискуссии юристов по вопросу о правосубъектности искусственного интеллекта [9, с. 46; 10, с. 11], о правовых свойствах цифровых объектов [11, с. $221 ; 12$, с. $104 ; 13$, с. 91; 14, с. 88; 15 , с. 5-7], об использовании онлайн-технологий в урегулировании споров [16, с. 476; 17, с. 283] и т.п. Следовательно, на уровне сознания не может быть «чистого» права, то есть существующего изолированного от иных социальных институтов, «неправовых» по своей сущности факторов.

В свою очередь, внутрисистемные свойства права отражают его строение, характер правового воздействия на общественные отношения, специфику правовых форм и типологию правового регулирования. Все эти свойства при этом имеют вполне эмпирическое выражение и проявляют себя, в частности, в текстах законов и судебных постановлений, в юридически значимых поведенческих актах, в конкретных мерах реализации юридической ответственности и т.п.

Изложенное дает основание полагать, что реальность права сама по себе не ограничена только пространством идеального, сферой человеческого мышления. Право, таким образом, принадлежит к сфере сознания ровно в той же степени, в которой оно относится к числу эмпирически воспринимаемых явлений объективной действительности. Таким образом, с некоторой долей условности допустимо говорить о двух принципиально различных онтологиях права - идеальной (конституируемой правопониманием, системой абстрактных понятий о правовом) и материально-эмпирической (опосредуемой всей системой чувственно воспринимаемых правовых явлений). Данная ситуация ярко проявляет себя в известном «противопоставлении» юридической теории и практики: первая по преимуществу нацелена на исследование онтологии права как идеального явления, вторая же - на прикладные разработки права как эмпирической действительности [18, с. 20]. Следует констатировать, что такое положение дел в принципе характерно для континентальной правовой традиции. Так, еще Цицерон, характеризуя состояние современной ему юриспруденции, писал: «У нас нет подлинного и ясного представления об истинном праве и о настоящей спра- 
ведливости, и мы пользуемся только их тенью и очертаниями» $[19$, с. 141], говоря в этом смысле прежде всего об узко-прикладном, фактически функциональном характере римской юриспруденции, нацеленной на обслуживание конкретных юридических практик ${ }^{1}$. Подобные характеристики видятся справедливыми и в отношении современной юриспруденции.

Итак, мы можем сделать вывод, что в настоящее время сложились две принципиально различные онтологии (а точнее - онтологические картины) права, ни одна из которых при этом не охватывает право как ичелостность, как системное образование, которому в равной мере присущи и идеальные, и эмпирические характеристики [21, с. 26-28]. Такая методологическая ситуация находит свое отражение в сегодняшней правовой теории, в которой наблюдается в связи с этим методологическая конкуренция типов правопонимания, терминологически обозначаемых в качестве «классического» и «постклассического» [22, с. 88-91]. Основанием такой ситуации является, с нашей точки зрения, проблема действительности права, в основе которой лежит вопрос о том, к какой сфере явлений принадлежит право per se. Классическое правопонимание в этом смысле отстаивает тезис об эмпирической сущности права, понимаемого в качестве системы общеобязательных норм социального поведения, исходящих от государства как политико-правовой организации общества, зафиксированных в нормативно-правовых актах и обеспеченных государственным принуждением [23, с. $104 ; 24$, с. 52; 25 , с. $180 ; 26$, с. $205 ; 27$, с. $332-341 ; 28$, с. $87 ; 29$, с. $137 ; 30$, с. 169 ; 31, c. 196].

В противовес приведенному подходу сторонники постклассического правопонимания обосновывают интерсубъективную природу права, оправдывающую интерпретацию права в качестве идеального по своей сущности явления, онтологическое «отображение... права в адекватном ему мыслительном образе» [32, с. $22 ; 33$, с. $5 ; 34$, с. $16 ; 35$, с. $209 ; 36$, с. 30]. Таким образом, устоявшееся в парадигме «нормальной науки» (Т. Кун) классическое правопонимание основывается на эмпирико-объективистских началах, а постклассическое, соответственно, на идеально-субъективистских. Тем самым правовая доктрина по существу не включает в свою парадигму целостную онтологию права, а, как уже было отмечено, репрезентирует лишь отдельные аспекты права как системного явления, его онтологические картины, взятые изолированно единицы правовой

\footnotetext{
По выражению Р. Иеринга, «история римского права до нашего времени знает только циферблат часов, не имея понятия об их механизме. Она не касается вопроса о скрытой силе, которая приводит в движение стрелку, и донельзя внешняя связь ее историко-юридического материала напоминает систематику счета прачки: сорочки, воротнички, носовые платки,-leges, senatusconsulta, constitutiones principum, etc» [20, с. 476].
}

действительности [37]. Данная ситуация осложняется набирающей темпы цифровизацией социальной сферы, резким смещением акцентов социальной деятельности в плоскость информационно-телекоммуникационного пространства и, наконец, появлением в этом пространстве «цифровых артефактов» ${ }^{2}$, по существу приобретающих характер экономических благ. Цифровое пространство - это качественно новый феномен современной цивилизации, который не вписывается ни в методологическую матрицу классического правопонимания (поскольку таковое нацелено на осмысление в первую очередь материальных явлений при помощи традиционных юридических конструкций $\left.{ }^{3}\right)$, ни в теоретическое пространство постклассического правопонимания (поскольку действительность цифрового пространства это действительность не столько мышления, сколько особой технологической сферы, в которой реализуются общественные отношения ${ }^{4}$ ). Тем самым можно констатировать, что все феномены, подлежащие научному осмыслению средствами юридической науки, условно можно разделить на материальные, идеальные и вирmуальные, находящиеся равным образом и вне сферы материального мира, и вне нашего сознания, и которые в настоящее время представлены системой явлений и процессов, складывающихся в информационно-технологическом пространстве. Данные виртуальные явления, не относящиеся ни к реальности сознания, ни к материально-эмпирической действительности, правовая наука в силу вышеназванных обстоятельств практически не в состоянии осмыслить адекватно их сущности, на что обращается внимание в современных исследованиях ${ }^{5}$.

\footnotetext{
2 О понятии артефакта см.: [38, с. 9].

${ }^{3}$ Характерна в этом смысле теоретическая позиция Ю. В. Козубенко по вопросу о существе механизма правового регулирования. «Механизма уголовно-правового регулирования нет как объекта реальной действительности,- утверждает автор,- в этом смысле он воспринимается как юридическое описание реальности (курсив наш- В.П., О.П.)». [39, с. 4]. В приведенном рассуждении усматривается ключевая установка классического правопонимания, а именно - восприятие права только как эмпирически воспринимаемой действительности. Здесь правовая теория предстает как рефлексия над текстуальной действительностью права и практикой его применения, а выработанные в данном процессе абстрактные понятия (как, например, понятие механизма правового регулирования) и созданные правовым сознанием идеальные объекты признаются не относящимися к правовой действительности. О методологических основаниях критики такого подхода см.: [1, с. 27].

${ }^{4}$ См. подробнее о процессах, протекающих в современном информационном обществе под влиянием права: [40].

${ }^{5}$ «Право,- пишет в связи с этим В.В. Архипов,- нацелено на регулирование реальности, но «жесткая реальность» доинформационного общества, в котором сложились основные институты права и само право как социальный институт, трансформируется в современную «игривую медиареальность», в которой сложно (но при этом необходимо!) найти принцип, по которому мы сможем определять ту область применения норм, имеющих предоставительно-обязывающий характер, которая не будет противоречить здравому смыслу, иными словами-не приведет к абсурду (курсив наш - В.П., О.П.)» [41, с. 139].
} 
В связи с этим нередко (а в последнее время - достаточно часто) исследователи призывают к рассмотрению права как науки в контексте типов научной рациональности, в частности - к определению характеристик права и правовой науки в контексте гносеологических установок постнеклассического типа. Так, по мнению Д.А. Пашенцева и Д.Р. Алимовой, соответствующее познавательное отношение к праву и правоведению обеспечит возможность сформулировать необходимую правовую модель регулирования отношения в цифровом пространстве [42, с. 102]. Т.Л. Воротилина, в свою очередь, утверждает, что «постнеклассические» установки в научном правопознании позволят сформулировать «материально-информационное понимание реальности» $[43$, с. 10] и тем самым должным образом осмыслить процессы цифровизации. Однако при этом, на наш взгляд, исследователи упускают из виду то обстоятельство, что типология научной рациональности была сформулирована ее автором В.С. Степиным применительно к методологии естественных наук, к числу которых правоведение не относится. В связи с этим эвристическая состоятельность данной методологической модели в контексте гуманитарно-научного познания представляется нам как минимум спорной ${ }^{1}$.

Однако следует признать, что «методологический диктат» естествознания и ориентация философии науки с самого ее зарождения в философском позитивизме О. Конта на осмысление характеристик естественно-научного познания неизбежно накладывает отпечаток и на философско-методологические рефлексии гуманитарных наук [46, с. 7; 32, с. 14-15]. Так, к примеру, Н. Н. Та-

\footnotetext{
В принципе следует подчеркнуть, что и идея об изначальной методологической и аксиологической нейтральности естественных наук является небесспорной. Подтверждением тому является обоснованное мнение О. Конта, который, выдвигая теорию о трех стадиях интеллектуальной эволюции человечества (теологической, метафизической и научной), замечает, что для средневековой науки «теологический дух должен был долгое время необходимым, в особенности для постоянного сочетания моральных и политических идей (курсив наш-В.П., О.П.)» [44, с. 13]. Тем самым именно субъективные установки и ценностно-целевые структуры общества (в первую очередь - огромная роль католических догматов в мышлении), которые с позиции типологии научной рациональности, стали характерны для естественных наук только в последней трети XX в. в значительной мере обусловливали развитие европейской науки (в том числе ее естественного направления).

Еще один аргумент против тезиса об отсутствии какого-либо влияния ценностно-целевых структур личности и общества на естественно-научную деятельность вплоть до эпохи постнеклассической научной рациональности усматривается в следующем тезисе Л.М. Косаревой: «В XVII в., когда контекст технологического использования новых теоретических концепций был еще неразвит,- отмечает автор,- несоизмеримо большую роль в признании теорий играли мировоззренческо-ценностные факторы: физика Аристотеля в XVII В. устарела не сколько «эмпирически» или «экономически», сколько «морально» [45, с. 119]. При этом Л.М. Косарева обоснованно подчеркивает: «Ценностная нейтральность естественнонаучного знания - это не реальность; это - социально полезный методологический миф, возникший, а точнее, «социально сконструированный». в позитивистской методологии науки не ранее начала XIX в.» [45, с. 119].
}

расов связывает идею различения объекта и предмета правоведения со становлением неклассической научной рациональности в контексте открытий А.Эйнштейна и В. Гейзенберга [47, с. 134]. В этом смысле, как утверждает сам исследователь, «теоретический план связан в основном с экстраполящией философских представлений о разграничении объекта и предмета науки на юриспруденциию (курсив наш - В.П., О.П.), выбором соответствующих контекстов описания и определением понятий объекта и предмета юридической науки» [48, с. 40]. Однако насколько оправдан такой методологический подход? Очевидно, что концепция различения объекта и предмета науки связана в заданном контексте именно с изменениями в методологии естествознания (в первую очередь - теоретической физики). Следовательно, именно в рамках методологической матрицы естествознания и формируется пространство философско-рефлексивных представлений об объекте и предмете науки. «Автоматическая» экстраполяция Н.Н. Тарасовым методологических оснований такого подхода на область правоведения как гуманитарной науки видится при этом едва ли обоснованной и представляется неверной по существу (тем более, что ранее сам исследователь верно отмечает, что «в плане методологии научного познания сравнивать юриспруденцию с естествознанием более чем сложно» [49, с. 26]). Вне сомнения, правоведению также присуща методологическая идея о различении объекта науки и ее предмета, но в то же время утверждать, что онтология этой идеи обусловлена именно соответствующими процессами в естествознании и осуществляется таким же образом, как и в методологии естественных наук, совершенно неправомерно (достаточно отметить, что проблему различения объекта и предмета правоведения обозначил еще задолго до зарождения этой идеи в методологии естествознания немецкий юрист Ф.-К. фон (авиньи ${ }^{2}$ ). Здесь правильнее, с нашей точки зрения, говорить не об изменениях в методологии правовой науки, опосредуемых соответствующей динамикой естествознания, а о произошедших на рубеже XIX - XX вв. «радикальных изменениях во всех сферах европейской культуры, в том числе и в стиле научного мышления» [32, с. 15], о трансформации всего образа социального мира, неизбежно нашедших отражение и в общеметодологических характеристиках научного познания [5, с. 467, 720]. Иными словами, идея неклассической научной рациональности (и, соответственно, представление о различении объекта и предмета науки) в естествознании является лишь частным проявлением указанных социокультурных изменений в области естественных наук, то есть следстви-

Так, в концепции Ф.-К. фон Савиньи достаточно отчетливо прослеживается идея о различении объекта юриспруденции (как этнической общности) и ее предмета как системы исторических фактов правового развития, юридической сущности народного духа — Volksgeist (см.: [50, с. 142-143; 51, s. $222 ; 52$, s. $149 ; 53$, s. 89]) 
ем, а не причиной, и тем более - не основанием для соответствующей типологии гуманитарно-научной рациональности [54, с. 9-10, 20-22].

В принципе, идея о рассмотрении права и, соответственно, о построении методологии юридической науки сообразно с философской типологией научной рациональности является имманентно присущей современному правоведению. В заданном контексте Е.В.Тимошина небезосновательно констатирует «избыточность «постнеклассики» в теории права» [32, с. 8], отмечая отсутствие достаточных методологических оснований для соответствующей концептуализации [32, с. 8]. Разделяя данный вывод уважаемого автора, отметим, что ситуация «постнеклассики» (то есть зависимости результатов исследования не только от характеристик объекта, но и от научно-познавательной методологии и социокультурных условий научного познания) была всегда характерна для юриспруденщии. Здесь достаточно обратить внимание на то обстоятельство, что, к примеру, в исследовательской практике глоссаторов, по сути заложивших методологический фундамент современной юридической науки, отчетливо прослеживается влияние ценностно-целевых структур общества (в частности, христианского богословия, из которого глоссаторы взяли отношение к тексту юстиниановой кодификации как к ratio scripta [55, с. 48; 56, с. 214; 57, p. 450-451], а также прямая зависимость между избранной исследовательской методологией (в частности, установками номинализма или реализма) и результатами познания [58, с. $62-63 ; 59$, с. 272]'.

Таким образом, цифровая эпоха поставила перед нашим правоведением фундаментальную проблему проблему оснований действительности права. Эта проблема, как уже было отмечено ранее, в актуальной теории права разрешается двумя качественно различными способами: либо представлением права как эмпирического феномена (в классическом правопонимании), либо отнесением его к числу идеальных объектов, социально-эпистемологических конструктов [63, р. 266-269] (что более характерно для постклассического понимания). Однако неспособность данных теорий в полной мере отразить специфику виртуальных аспектов права, не относящихся ни к эмпирической, ни к идеальной действительности, обусловила формирование в нашем научном правосознании установки

\footnotetext{
' Такая характеристика справедлива в отношении не только юридической науки, но и юридической практики. Так, представители американских школ правового реализма и критических правовых исследований убедительно показывают, что решения, принимаемые судьями, зависят не только от объективных факторов (фактических обстоятельств конкретного дела, юридических норм и прецедентных правовых позиций), но и также - от методологии судейского познания и от факторов политико-идеологического и социокультурного плана (см.: [60, р. 62; 61; 62, р. 72-76]).
}

на интерпретацию правовой действительности в соответствии с гносеологией постнеклассической научной рациональности, с тем чтобы обеспечить возможность ценностно-целевого и методологического измерения права в контексте цифровизации. С нашей точки зрения, процессы информатизации общественных отношений, придания им новой - цифровой - формы становятся для нашей теории права своего рода моментом истины, фактором, определяющим методологическую состоятельность юриспруденции в ситуации отмечаемой конкуренции классического и постклассического правопонимания. Поэтому основные и первоочередные проблемы отечественного правоведения в сегодняшних реалиях - это в первую очередь проблема его методологии и проблема правопонимания, сущности права. В этом смысле мы ставим перед собой задачу осуществить теоретическую концептуализацию данных проблем в контексте реалий информационного общества.

В этой связи, рассматривая проблему действительности права, правопонимания, представляется уместным обратиться к ее философским контекстам. В философии вопрос о действительности явления традиционно рассматривается сквозь призму его онтологических оснований, то есть отношений и структур, являющихся исходными по отношению к явлению [64, с. 279]. «Основание,- писал в связи с этим М. Хайдеггер,- есть то, на чем все покоится, что предлежит всякому сущему В качестве того, что его несет» [65, с. 209]. «Вопрос об основании, - замечает в связи с этим Л.В. Баева,- это... вопрос о смысле и законе присутствия, в то время как вопрос о бытии - это вопрос о его фактичности» [66, с. 15]. Тем самым действительность права конституируется его онтологическими основаниями, исходными условиями, оправдывающими принципиальное бытие права как самостоятельного социального феномена. В таком контексте необходимо проследить процесс образования права, его институционального оформления.

С точки зрения устоявшихся представлений о праве (то есть классического правопонимания) его образование напрямую связано с волей государства; имманентно присущий праву позитивный, государственно обеспеченный характер оправдывает в такой онтологической схеме отождествление права с государственным велением. Тем самым, с нашей точки зрения, процессу образования права придается в этом смысле односторонний характер: право по сути не связывается с социальными условиями и практиками, а сводится к односторонне-властному предписанию, конституируемому публичной волей. Однако в этом смысле целесообразно отметить, что любой процесс позитивного правотворчества непосредственно связан с характером регулируемых отношений. Так, цифровизация гражданского оборота и стремительное развитие информацион- 
но-телекоммуникационных технологий стали теми факторами, которые обусловили, в частности, включение в перечень объектов гражданских прав цифровых прав (статья 141.1 Гражданского кодекса Российской Федерации [67] (далее - ГК)), установление правовых оснований для использования технологии смарт-контракта как способа автоматического исполнения обязательств (часть 2 статьи 309 ГК), регламентацию оказания информационных услуг (статья 783.1 ГК [68]) и т.п. Практика привлечения инвестиций с использованием электронных платформ, в свою очередь, обусловила принятие отдельного федерального закона, регулирующего краудфандинговую деятельность (Федеральный закон от 2 августа 2019 г. N259-Ф3 «О привлечении инвестиций с использованием инвестиционных платформ и о внесении изменений в отдельные законодательные акты Российской Федерации» [69]). В этой связи мы можем сделать вывод, что государственное правотворчество представляет собой реакцию на изменения в актуальных социальных практиках. Здесь нам видится уместным привести следующее мнение немецкого социолога и юриста О. Эрлиха. «Люди, которые записывали законы Двенадцати таблиц, Салическую правду, Саксонское зерцало,- писал исследователь,- познавали право своего времени из непосредственного наблюдения (курсив наш-В.П., О.П.). Поэтому их задачей было собрать именно то право, с которым они имели дело, и зафиксировать его в правовых предложениях. Это относится и к той части права, с которой работают современные юристы» [70, с. 478]. Таким образом, даже в условиях возможности государства произвольно формулировать правовые предписания (в том числе и не сообразующиеся с потребностями социальной деятельности [71, с. 264] $]^{1}$ ) мы не можем однозначно утверждать, что единственным источником права выступает воля государства. Правотворчество в этом смысле представляет собой односторонне волеизъявление публичного субъекта ровно в той же мере, в которой оно является необходимостью текстуального оформления и нормативной регламентации уже сложившихся в общуестве отношений, воспринимаемых в связи с этим в качестве правовых. Тем самым, полемизируя со сторонниками классического правопонимания, мы можем утверждать, что исходящее от государства позитивное право - это в первую очередь способ оформления права, уже сложившегося в соииальных практикаx. Издавая законы, в которых фиксируется правовой режим цифровых прав, осуществляется регулирование оказания информационных услуг и краудфандинга, государство тем самым признает объективный правовой характер соответствуюших соччиальных явлений.

\footnotetext{
1 Достаточно радикальную оценку такому положение дел дает Д. В. Осинцев, отмечая, что «право есть принимаемые социумом способы вторжения в устоявшуюся сочиокультурную ситуацию и придание ее некой консервативной традиции после изменения естественного хода дел и замены его нормативным порядком управления» ([72, с. 13]).
}

В этом смысле допустимым представляется утверждать, что классическое правопонимание по сути подменяет содержание права его формой (законом, подзаконным актам и иными принятыми в актуальных социокультурных условиях формами выражения права вовне).

Ergo, можно констатировать, что правовой характер придается общественным отношениям «изнутри» их самих, и только впоследствии фиксируется «извне» в тексте закона. Такая логика прослеживается в историко-антропологических характеристиках правогенеза, показывающих процесс зарождения права первоначально в форме первобытного обычая, «общинного права», а затем - последовательный переход к более развитым формам права, в первую очередь - к формам его государственно-властной объективации [73, с. 83-35].

Как пишет по данному поводу Д.В. Осинцев, «нормы права не сосуществуют наряду с иныли социальными нормами, а придают им сочиально значимый, официальный статус, замещуают их, а также создают новачии в регламентации сочииальной деятельности» [72, с. 12]. Иными словами, в интерпретации автора правовые нормы - это по сути официальная, государственно-признанная форма объективации тех или иных социальных норм, а не особый институциональный регулятор общественного поведения наряду с моралью, религией, обычаями, традициями и корпоративными нормами. Однако позиция автора не решает в этом смысле нашу познавательную задачу, поскольку даже в контексте такого подхода не снимается вопрос о том, почему те или иные сочиальные явления определяются в качестве правовых ${ }^{2}$. Ведь если исходить из того, что право зарождается внутри общественных отношений, то логично предположить, что человек понимает правовой характер этих отношений ${ }^{3}$. В этой связи для разрешения проблемы действительности права имеет существенное значение ответ на вопрос о том, чем обусловлено отнесение явлений и процессов в информационно-технологическом пространстве к числу правовыхт?

С нашей точки зрения, изложенное обусловливает необходимость в концептуальном различении понимания права и понимания правового. Если первое пред-

В этой связи следует безусловно согласиться с утверждением И.П. Малиновой о том, что «В законотворческой и правоприменительной деятельности очень важно учитывать специфику эпохи, в силу чего членам юридического сообщества необходим мониторинг существенных изменений в жизни общества» [74, с. 9].

3 Разумеется, такое понимание, с нашей точки зрения, носит скорее интуитивный характер хотя бы ввиду того, что развернутая юридическая концептуализация тех или иных социальных практик (то есть не только понимание правовой сущности явление, но и знание его непосредственных юридических характеристик) вряд ли возможна вне соответствующей профессиональной подготовки (см.: [75, с. 85]). 
ставляет собой в первую очередь профессиональную рефлексию объективно наличествующего права, взятого В том или ином познавательном отношении и онтологическом представлении, то во втором случае мы по сути сталкиваемся с определением права в ситуации, когда его нет в объективном смысле. «Глубочайшей сущностью права - пишет в связи с этим Г.К. Варданянц - является... «ощущение права», возникающее как предпосылка рождения спроса на права» [76, с. 20]. В этом контексте социальный генезис права описывается исследователем как взаимосвязанное и взаимообусловленное формирование «правовых ожиданий», «спроса на права» и «предложения права» [76, с. 21]. При всей неоднозначности такого терминологического обозначения мы не можем, тем не менее, не отметить, что Г.К. Варданянц совершенно правильно указал, что первоначально истоки права формируются на уровне понимания, а не на уровне знания. Тем самым реконструкция процесса образования права нуждается в герменевтической интерпретации.

Здесь представляется уместным обратиться к понятию понимания, сформулированному В. Дильтеем в качестве объективации индивидуального переживания. «Понимание впервые снимает ограниченность индивидуального переживания,- писал В. Дильтей,-и оно же, с другой стороны, придает личным переживаниям характер жизненного опыта» [77, s. 141]. «Роль первичного понимания состоит в том, чтобы овладеть собственными переживаниями, уметь их выразить - пишет в связи с этим М.Е. Соболева.- Схваченные в понимании и выраженные в знаке, переживания превращаются в жизненный опыт, в знание о собственной жизни» $[78$, с. 76]. Тем самым понимание, направленное первоначально на индивидуально-психическое переживание, впоследствии объективируется в опыт, который, в свою очередь, опосредует формирование знания, понятия о том или ином феномене.

Ergo, с нашей точки зрения, понимание правового первоначально формируется в контексте индивидуально-психической картины мира как особый концепт действительности, то есть область специальных значений и смыслов, придаваемых определенному виду социальных практик [79, с. 47; 80, с. 20; 81, с. 242-243; 82, с. 149]. В этом контексте концепт предстает в первую очередь в качестве особой формы познания действительности, основанной на воспроизведении смыслов [83, с. 228], которое является «условием возможности конструктивной деятельности человеческого разума» [84, с. 57]. В процессе оформления права в практике общественных отношений концепт предстает как отношение денотата (конкретного предмета или явления эмпирической действительности) и смысла как способа представленности социально значимых свойств денотата в мышлении [85, с. 351]. «Право,- пишет в связи с этим В. А. Белов,- это возможность (максима) всеобщего поведения, являющаяся продуктом компромисса между свободой личности и сплочением общества. Право ощущается с помощью правового чувства (если угодно - интуиции) и, будучи воспринятым, принимает вид правовых ощущений,обоснованно замечает далее автор.- Именно они и облекаются в объективные формы: нормативные акты, обычаи, судебные и административные акты, акты изъявления воли частных лиц и, наконец, в ряд научных категорий» $[86, \text { с. 57] }]^{1}$.

Изложенное, с нашей точки зрения, позволяет судить о том, что понимание правового представляет собой особый гносеологический процесс, основанный на переживании явления и придании ему правовых смыслов в контексте соотношения субъективного притязания, поведения субъекта, которому адресовано данное притязание, и социального итога соответствующего отношения. Тем самым схематично концепт правового можно представить через триаду: «право» (притязание на что-либо) - «обязанность» (необходимость другого лица предоставить денотат притязания) - «ответственность» (негативные последствия, наступающие для обязанного лица при отказе предоставить денотат притязания). Именно такие характеристики, с нашей точки зрения, присущи отношениям в информационно-телекоммуникационном пространстве до их правового оформления на уровне позитивного права.

Обоснованность заявленного тезиса проявляется, на наш взгляд, в контексте формирования представлений о правовой сущности такого результата интеллектуальной деятельности как программа для электронных вычислительных машин (далее - программа для ЭВМ, программное обеспечение).

История современного программирования для ЭВМ берет свое начало в электромеханическом периоде развития вычислительной техники (конец XIX - 40-е гг. XX вв.) и связана в первую очередь с изобретениями немецкого инженера К. Цузе, разработавшего в 1934 г. модель автоматического калькулятора [88, с. 67]. Именно в указанный период начинаются систематические разработки программного обеспечения, которое первоначально не имело собственного правового режима. В такой ситуации объективно актуализировался вопрос о правовой модели охраны прав изготовителя программы для ЭВМ на ее исходный текст и объектный код. Соответствующая проблема, в частности, начинает активно обсуждаться в отечественном правоведении в 1970-х гг.

Весьма оригинально описывает процесс образования права О.С. Иоффе: «Что существуют нотные знаки - видно всем, но где же музыка? Ответ не менее прост, чем вопрос: нормы права так же воплощаются в законодательных актах, как музыка в нотных знаках» ([87, с. 67]). 
в контексте многообразных исследовательских подходов к определению правового режима программ для ЭВМ (авторско-правового, патентно-правового и др.) [89, с. 53; 90, с. 22-25]. Таким образом, изначально не урегулированный правом режим программ для ЭВМ признавался объективно имеющим правовой характер в силу наличия самого притязания автора на защиту изготовленной им программы от внешних посягательств и обусловленной этим необходимости других лии воздержсваться от таких притязаний.

Сходная ситуация формируется и в настоящее время в контексте отношений между субъектами взаимодействия в виртуальной сфере. Показательным примером в этом смысле является дело «Брэг против Линден Рисёч Инк.» (Bragg v. Linden Research Inc., 487 F. Supp. 2d 593 (E. D. Pa. 2007)).

Согласно материалам дела, истец обратился в суд с иском к администратору онлайн-игры, основанием которого послужила, по мнению истца, необоснованная блокировка его аккаунта в онлайн-игре Second Life, вследствие которой истец лишился виртуальных активов на общую сумму около 5000 долл. США. Ответчик, возражая против иска, указал в судебном заседании, что блокировка аккаунта истца была обоснована его неправомерным поведением. Так, ответчик отметил, что истец необоснованно получил доступ к игровым аукционам, на которых он приобрел по сниженной цене виртуальный земельный участок. В итоге дело было окончено мировым соглашением, и окружной суд избежал необходимости юридической квалификации отношений в виртуальном пространстве. Однако в заданном контексте наиболее важен сам факт принятия такого иска к производству суда. Данный факт, с нашей точки зрения, свидетельствует о признании отношений в виртуально-игровой сфере имеющими правовой характер даже в отсутствии соответствующего регулирования [91, с. 112]. При этом, с нашей точки зрения, основанием такого подхода является объективное существование притязания, необходимость должного поведения другого лица в связи с наличием этого притязания и риск наступления негативных последствий для обязанного лица.

Итак, сказанное позволяет судить о том, что основанием действительности права является не только наличие позитивного права, но и понимание правового характера того или иного общуественного отношения. Такое понимание, как было отмечено ранее, можно представить как соотношение «права» (притязания на что-либо), «обязанности» (необходимости другого лица предоставить денотат притязания) и «ответственности» (негативных последствий, наступающие для обязанного лица при отказе предоставить денотат притязания). Соответствующую концептуализацию права, актуализирующуюся прежде всего в контексте отношений в виртуальном пространстве, нельзя однозначно отнести ни к классическому, ни к постклассическому правопониманию, поскольку в такой логике действительность права связана прежде всего с особым способом познавательного отношения к социальной действительности, несводимой при этом ни к материально-эмпирическому, ни к субъективно-мыслительному содержанию. Здесь эмпирический и идеально-мыслительный аспект правовой действительности соединяются воедино при социальном конструировании права как концеепта, идущего от индивидуально-жизненного переживания, формирования социальных притязаний, к их системно-практической организации и последующему нормативно-правовому оформлению (появлению права как социального конструкта) [92, с. 37]. Тем самым, с нашей точки зрения, актуализируется применение герменевтико-диалектической методологии в научном познании социальных явлений информационно-технологической сферы. Эпистемологическая организация современного правоведения в соответствии с установками философской герменевтики позволяет, по нашему мнению, избежать неоправданной подмены юридического концепта отношений в цифровой сфере их позитивно-правовой моделью, обеспечивает представление права как объективно формирующегося в пространстве социальных практик нормативного регулятора отношений, несводимого ни к тексту закона, ни к индивидуально-субъективному восприятию. В этой связи, с нашей точки зрения, актуальные внутринаучные характеристики правопознания не могут быть объяснены в контексте типологии научной рациональности. Роль данной концепции мы видим прежде всего в расширении методологических границ правоведения цифровой эпохи за счет привлечения концептуальных схем, методологических подходов из технической и технологической мысли.

Таким образом, проблема оснований действительности права (рассматриваемая, как правило, в контексте классического или постклассического правопонимания) нуждается в дальнейшей теоретической разработке в контексте реалий цифровой эры. По нашему мнению, от решения данной проблемы зависит дальнейшее принципиальное будущее права в условиях, когда виртуальное пространство характеризуется стихийным оформлением собственных регуляторов поведения, природа которых не поддается однозначному юридическому определению. В этом смысле принципиально необходимым становится развитие в первую очередь общетеоретических правовых исследований, задающих вектор развития отраслевого правового знания об особенностях общественных отношений в информационно-телекоммуникационном пространстве. 


\section{ЛИТЕРАТУРА}

1. Петражицкий Л. И. Введение в изучение права и нравственности. Основы эмоциональной психологии. 3-е изд. — СПб.: Тип. Ю. Н. Эрлих, 1908.

2. Ц Цицерон Марк Туллий. Три трактата об ораторском искусстве / Пер. с лат. Ф. А. Петровского, И. П. Стрельниковой, М. Л. Гаспарова; под ред. М. Л. Гаспарова.- М.: Научно-издательский центр «Ладомир», 1994.

3. Розов М.А. 0 природе идеальных объектов науки // Философия науки. 1998, № 4.

4. Берг Л. Н. Исследование правового воздействия: методология, теория, практика: Дис. ... д-ра юрид. наук. — Екатеринбург: Уральский государственный юридический университет, 2018.

5. Сорокин П. А. Социальная и культурная динамика: исследование изменений в больших системах искусства, истины, этики, права и общественных отношений / П. А. Сорокин; Пер. с англ. В. В. Сапова.— СПб.: Изд-во РХГИ, 2000.

6. Честнов И.Л. Общество и юриспруденция на исходе второго тысячелетия: Монография. — СПб.: 0-во «Знание», СПбИВЭСЭП, 1999.

7. Афанасьев В.Г. Проблема целостности в философии и биологии.-М.: Мысль, 1964.

8. Садовский В. Н. Методология науки и системный подход // Системные исследования. Ежегодник. - М.: Наука, 1977.

9. Архипов В.В., Наумов В. Б. Искусственный интеллект и автономные устройства в контексте права: о разработке первого в России закона о робототехнике // Труды СПИИРАН. 2017, вып. 6 (55).

10. Пономарева Е. В. Субъекты и квазисубъекты права: теоретико-правовые проблемы разграничения: Дис. ... канд. юрид. наук. - Екатеринбург: Уральская государственная юридическая академия, 2019.

11. Белых В.С., Егорова М. А. Понятие, значение и правовое регулирование криптовалюты в современных условиях гармонизации и развития цифровых правоотношений // Проблемы гармонизации экономических отношений и права в цифровой экономике.- М.: Юстицинформ, 2020.

12. Лисаченко А. В. Право виртуальных миров: новые объекты гражданских прав // Российский юридический журнал. 2014, № 2 (95).

13. Мефодьева К. А. Цифровые данные как объект гражданско-правового регулирования в Германии, США и России: Дис. ... канд. юрид. наук. - М.: Институт законодательства и сравнительного правоведения при Правительстве Российской Федерации, 2019.

14. Мурзин Д. В. Информация в третьем тысячелетии — объект гражданских прав? // Экономическое правосудие в Уральском 0круге. 2019, № 3 (51).

15. Хрусталева А.В. Электронные денежные средства как объект гражданского правоотношения: Автореф. дис. ... канд. юрид. наук.- СПб.: СПбГЭу,

16. Курочкин С. А. Онлайн-арбитраж: правовые аспекты // Право в сфере Интернета: сборник статей / Отв. ред. М. А. Рожкова. — М.: Статут, 2018.

17. Федорова В.Д. Инструменты онлайн-системы судебных взаимоотношений в рамках формирования глобализированной судебной системы // Вопросы российского и международного права. 2019, т. 9. № 4А.

18. Тарасов Н. Н. Юридическая наука и юридическая практика: соотнесение в методологическом контексте (о практичности юридической науки и научности юридической практики) // Российский юридический журнал. 2012, № 3 (84).

19. Цицерон. 06 обязанностях // Цицерон. 0 старости. 0 дружбе. 06 обязанностях.-М.: Наука, 1974.

20. Иеринг Р. 0 задаче и методе истории права // Журнал Министерства юстиции. 1896, № 2.

21. Блауберг И. В. Целостность и системность // Системные исследования. Ежегодник. - М.: Наука, 1977.

22. Сизова Н. М. Классическое и постклассическое правопонимание: онтологические, гносеологические, аксиологические и эпистемологические критерии соотношения // Философия права. 2014, № 1 (62).

23. Алексеев С. С. Общая теория права: В 2-х т. Т. І.— М.: Юридическая литература, 1981.

24. Алексеев С. С. Теория права.- М.: Издательство БЕК, 1995.

25. Егоров С. Н. Аксиоматические основы теории права.- СПб.: Лексикон, 2001.

26. Любашиц В.Я., Мордовцев А. Ю., Мамычев А. Ю. Теория государства и права.- М.: РИОР, 2014.

27. Марченко М. Н. Проблемы теории государства и права. Учебник.- М.: Проспект, 2001.

28. Общая теория государства и права: учебник / под ред. С. Ю. Наумова, А. С. Мордовца, Т. В. Касаевой. — Саратов: Саратовский социально-экономический институт (филиал) РЭУ им. Г. В. Плеханова, 2018. С. 87;

29. Перевалов В. Д. Теория государства и права: учебник для бакалавров / В. Д. Перевалов.— 2-е изд., перераб. и доп. — М.: Издательство Юрайт, 2012.

30. Сабо И. Основы теории права: Пер. с венг. / Под ред. и с вступ. статьей д-ра юрид. наук В. А. Туманова. — М.: Прогресс, 1974.

31. Теория государства и права: Учебник / Под ред. В. К. Бабаева.— М.: Юристъ, 2003.

32. Тимошина Е. В. Классика, постклассика... неоклассика: к обоснованию контрпостмодернистской программы в теории права // Известия высших учебных заведений. Правоведение. 2014, № 4 (315).

33. Веденеев Ю. А. Грамматика правопорядка: монография / науч. ред. В. В. Лазарев.— М.: РГ-Пресс, 2018.

34. Малахов В. П. Мифы современной общеправовой теории: монография / В. П. Малахов. — М.: ЮНИТИ-ДАНА: Закон и право, 2013.

35. Поляков А. В. Что есть право? // Известия высших учебных заведений. Правоведение. 2012, № 6 (305).

36. Честнов И. Л. Правовая реальность как предмет постклассической философии прав // Российский журнал правовых исследований. 2019, т. 6. № 2 (19).

37. Правовая жизнь в современной России: теоретико-методологический аспект / Под ред. Н. И. Матузова, А. В. Малько.— Саратов: ГОУ ВПо «Саратовская государственная академия права», 2005.

38. Вартофский М. Модели. Репрезентация и научное понимание / Пер. с англ. Общая редакция и предисловие И. Б. Новика и В. Н. Садовского.- М.: Прогресс, 1988. 
39. Козубенко Ю. В. Уголовно-процессуальные аспекты межотраслевого механизма уголовно-правового регулирования: Дис. ... д-ра юрид. наук. — Екатеринбург: Уральский государственный юридический университет, 2018.

40. Пучков 0.А., Пучков В. О. Право, информация, цифровые технологии: синергия технотронной эры. Монография. Екатеринбург: Уральская книга. 2019.

41. Архипов В. В. Семантические пределы права в условиях медиального поворота: теоретико-правовая интерпретация: Дис. ... д-ра юрид. наук.- СПб.: СПбГУ, 2019.

42. Пашенцев Д.А., Алимова Д. Р. Новации правотворчества в условиях цифровизации общественных отношений // Государство и право. 2019 , № 6.

43. Воротилина Т.Л. Постнеклассические тенденции в западной и российской традициях правопонимания: Автореф. дис. ... канд. юрид. наук. - Нижний Новгород: Нижегородский государственный университет им. Н. И. Лобачевского, 2002.

44. Конт 0. Дух позитивной философии: Слово о положительном мышлении. Пер. с фр. / Предисл. М. М. Ковалевского. Изд. 2-е. - М.: Книжный дом «ЛИБРОKOM», 2011.

45. Косарева Л. М. Этические идеалы и познание природы // Косарева Л. М. Рождение науки Нового времени из духа культуры.- М.: Издательство «Институт психологии РАН», 1997.

46. Степин В.С. Философия науки: общие проблемы: учебник для аспирантов и соискателей ученой степени кандидата наук / В.С. Степин.- - М.: Гардарики, 2006.

47. Тарасов Н. Н. Методологические проблемы юридической науки.— Екатеринбург: Издательство Гуманитарного университета, 2001.

48. Тарасов Н. Н. Объект и предмет науки как методологическая проблема современной юриспруденции // Российский юридический журнал. 2017, № 6 (117).

49. Тарасов Н. Н. Объект и предмет юридической науки: подходы и методологические смыслы различения // Известия высших учебных заведений. Правоведение. 2010, № 1 (288).

50. Савиньи Ф.-К. фон. Система современного римского права. Т. І / Пер. с нем. Г. Жигулина; Под ред. О. Кутателадзе, В. Зубаря.— М.: Статут, 2011.

51. Savigny F.C. von. System des heutigen Römischen Rechts. Bd. 3. - Berlin: Bei Veit und Comp., 1840.

52. Savigny F.C. von. Vom Beruf unsrer Zeit für Gesetzgebung und Rechtswissenschaft.— Berlin: Mohr und Zimmer, 1814.

53. Savigny F.C. von. Vorlesungen über juristische Methodologie 1802-1842 / Herausgegeben und eingeleitet von A. Mazzacane. — Frankfurt am Main: Vittorio Klostermann, 1993.

54. Тимошина Е. В. Теория и социология права Л.И. Петражицкого в контексте классического и постклассического правопонимания: Автореф. дис... д-ра юрид. наук.-СПб.: СПбГУ, 2010.

55. Глухарева Л. И. Система права в контексте правовой догматики // Система права в классическом и посткласстическом измерениях: Коллективная монография по итогам круглого стола № 6 в Московском ин-ституте государственного управления и права; под ред.д.ю.н., профессора А. Г. Чернявского и д.ю.н., профес-сора И. Л. Честнова.— М.: Русайнс, 2016.

56. Павлов В. И. Антропологическая концепция права и юридическая герменевтика: методологические параллели // Парадигмы юридической герменевтики: монография / под общ. ред. Е. Н. Тонкова, И. Л. Честнова. — СПб.: Алетейя, 2017.

57. Re E. D. The Roman Contribution to the Common Law // Fordham Law Review. 1961, Vol. 29. Iss. 3

58. Грабарь В.Э. Римское право в истории международно-правовых учений: Элементы международного права в трудах легистов XII — XIV вв. - Юрьев: Тип. К. Маттисена, 1901.

59. Полдников Д. Ю. Контракт и пакт в доктрине глоссаторов: XII — XIII ВВ.: Дис. ... канд. ист. наук. — М.: Институт всеобщей истории Российской Академии наук, 2005.

60. Greenawalt K. Law and Objectivity. - New York: Oxford University Press, 1992.

61. Hutchinson A.C. (ed.). Critical Legal Studies. — Totowa: Rowman \& Littlefield Publishers, Inc., 1989.

62. Llewellyn K. The Brumble Bush: On our Law and its Study. — New York: Oceana, 1930.

63. Gergen K. The Social Constructionist Movement in Modern Social Psychology // American Psychologist. 1985, № 40 (3).

64. Котелевский Д. В. Грани (-) новой онтологии // Онтология: учебное пособие в 2-х частях / науч. ред. Е. В. Бакеева, отв. ред. 0. Н. Томюк. Ч. І.—- Екатеринбург: Издательский дом «Ажур», 2015.

65. Хайдеггер М. Положение об основании // Хайдеггер М. Положение об основании. Статьи и фрагменты / Пер. с нем., глоссарий, послесловие 0.А Коваль, предисловие Е. Ю. Сиверцева.— СПб.: Лаборатория метафизических исследований философского факультета СПбГу; Алетейя, 2000.

66. Баева Л. В. Ценностные основания бытия // Вестник Оренбургского государственного университета. 2003, № 5 .

67. Гражданский кодекс Российской Федерации: часть первая от 30 ноября 1994 г. N51-Ф3 // Собрание законодательства Российской Федерации от 5 декабря 1994 г. N32. С. 3301.

68. Гражданский кодекс Российской Федерации: часть вторая от 26 января 1996 г. N14-Ф3 // Собрание законодательства Российской Федерации от 29 января 1996 г. N5. Ст. 410.

69. «0 привлечении инвестиций с использованием инвестиционных платформ и о внесении изменений в отдельные законодательные акты Российской Федерации»: Федеральный закон от 2 августа 2019 г. N259-Ф3 // Собрание законодательства Российской Федерации от 5 августа 2019 г. N31. С. 4418.

70. Эрлих 0. Основоположение социологии права / Пер. с нем. М. В. Антонова; Под ред. В. Г. Графского, Ю. И. Гревцова. — СПб.: 000 «Университетский издательский консорциум», 2011.

71. Сырых В. М. Логические основы общей теории права. Т. 3. Современное правопонимание.— М.: Российская академия правосудия, 2007.

72. Осинцев Д. В. Юридические техники и юридические технологии: очерк альтернативного право-понимания // Российский юридический журнал. 2018, № 4 (121). 
73. Герасимова Н. П. Генезис права // Вестник Уральского института экономики, управления и права. 2015, № 2.

74. Малинова И. П. Философия права: учебник / И. П. Малинова.- М.: Норма: ИНФРА-М, 2020.

75. Белов В. А. Учение о сделке в российской доктрине гражданского права (литературный обзор) // Сделки: проблемы теории и практики: Сборник статей.М.: Исследовательский центр частного права, 2008.

76. Варданянц Г. К. Социальный генезис права: гештальтсоциологический анализ: Автореф. дис. ... д-ра соц. наук.— М.: МГУ, 2008.

77. Dilthey W. Der Aufbau der geschichtlichen Welt in den Geisteswissenschaften.— Leipzig und Berlin: B. G. Teubner, 1927.

78. Соболева М. Е. Философская герменевтика: понятия и позиции.—- М.: Академический проект, 2013.

79. Абеляр П. Тео-логические трактаты: Пер. с лат. / Вступ. ст., сост. Неретиной С. С.— М.: Прогресс, Гнозис, 1995.

80. Гаджиев Г. А. Онтология права (критическое исследование юридического кон-цепта действительности): монография / Г. А. Гаджиев. - М.: Норма: ИНФPA-M, 2013.

81. Зиновьев А. А. Фактор понимания / А. А. Зиновьев. - М.: Алгоритм, Эксмо, 2006. С. 242-243;

82. Маркова Л. А. Философия из хаоса. Ж. Делез и Ф. Гваттари о философии как творчестве концептов // Вопросы философии. 2002 , № 3.

83. Кондаков Н. И. Логический словарь. - М.: Наука, 1971.

84. Тимошина Е. В. Право как «идея», как «фикция» и как «факт»: 0 номинализме и реализме в теории права // Труды Института государства и права Российской Академии Наук. 2013, № 4.

85. Фреге Г. Смысл и денотат // Семиотика и информатика. Сборник научных статей. Вып. 35. — М.: Русские словари, 1997.

86. Белов В. А. Объяснение (эссе о юристах и юридической деятельности) // Корпоративный юрист. 2006, № 1.

87. Иоффе 0.С. 0 понимании советского права // Советское государство и право. 1979, № 8.

88. Казакова И. А. История вычислительной техники: учеб. пособие / И. А. Казакова. — Пенза: Изд-во ПГУ, 2011.

89. Быков С. Н. Проблемы становления законодательства об охране компьютерных программ // Интеллектуальная собственность. Авторское право и смежные права. 2012, № 3 .

90. Рясенцев В.А., Мартемьянов В.С., Масляев А. И. Правовое регулирование отношений, основанных на создании и использовании алгоритмов и программ // Советское государство и право. 1987, № 8.

91. Архипов В. В. Виртуальное право: основные проблемы нового направления юридических исследований // Известия высших учебных заведений. Правоведение. 2013, № 2 (307).

92. Веденеев Ю. А. Интерпретации права как культурно-исторический феномен: категория и институт // Актуальные проблемы российского права. 2016, № 5 (66).

() Пучков Владислав Олегович, Пучков Олег Александрович ( puchkovandpartners@gmail.com ).

Журнал «Современная наука: актуальные проблемы теории и практики»

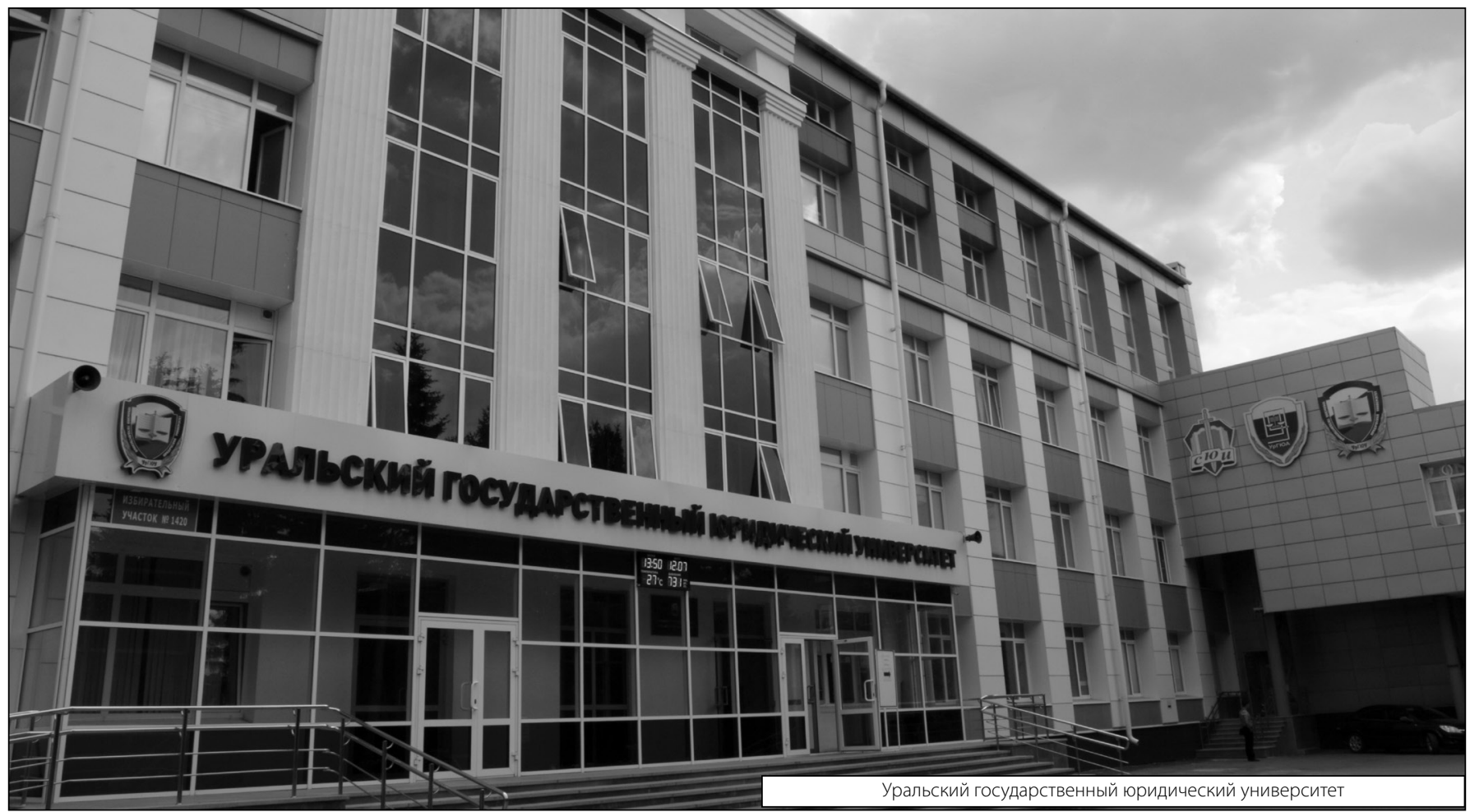

